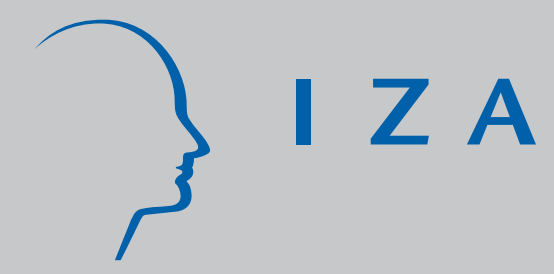

IZA DP No. 177

Immigrant Adjustment in Israel:

Literacy and Fluency in Hebrew and Earnings

Barry R. Chiswick

Gaston Repetto

J uly 2000 


\title{
Immigrant Adjustment in Israel: Literacy and Fluency in Hebrew and Earnings
}

\author{
Barry R. Chiswick \\ Department of Economics, University of Illinois at Chicago and IZA, Bonn \\ Gaston Repetto \\ Department of Economics, University of Illinois at Chicago
}

Discussion Paper No. 177

July 2000

\author{
IZA \\ P.O. Box 7240 \\ D-53072 Bonn \\ Germany \\ Tel.: +49-228-3894-0 \\ Fax: +49-228-3894-210 \\ Email: iza@iza.org
}

This Discussion Paper is issued within the framework of IZA's research area Mobility and Flexibility of Labor Markets. Any opinions expressed here are those of the author(s) and not those of the institute. Research disseminated by IZA may include views on policy, but the institute itself takes no institutional policy positions.

The Institute for the Study of Labor (IZA) in Bonn is a local and virtual international research center and a place of communication between science, politics and business. IZA is an independent, nonprofit limited liability company (Gesellschaft mit beschränkter Haftung) supported by the Deutsche Post AG. The center is associated with the University of Bonn and offers a stimulating research environment through its research networks, research support, and visitors and doctoral programs. IZA engages in (i) original and internationally competitive research in all fields of labor economics, (ii) development of policy concepts, and (iii) dissemination of research results and concepts to the interested public. The current research program deals with (1) mobility and flexibility of labor markets, (2) internationalization of labor markets and European integration, (3) the welfare state and labor markets, (4) labor markets in transition, (5) the future of work, (6) project evaluation and (7) general labor economics.

IZA Discussion Papers often represent preliminary work and are circulated to encourage discussion. Citation of such a paper should account for its provisional character. 


\section{ABSTRACT \\ Immigrant Adjustment in Israel: Literacy and Fluency in Hebrew and Earnings*}

This paper is an analysis of the determinates of Hebrew language speaking and writing skills and the determinates of earnings among adult male Jewish immigrants in Israel, using the 1972 Census of Israel. Among other findings, Hebrew speaking skills and Hebrew literacy are shown to increase with level of schooling and duration in Israel, but to decrease with age at migration and if many others in the area in which the respondent lives speak the same origin language. Country of origin and family structure also matter.

Earnings are found to increase with level of schooling, duration in Israel, pre-immigration labor market experience and proficiency in both speaking and writing Hebrew. Those who speak Hebrew on a daily basis as a primary or only language and who can write a letter in Hebrew earn about 20 percent more than those who do neither. Controlling for these variables, as well as country of origin, English speakers earn about 15 percent more and Arabic speakers earn 2 percent less than Hebrew speaking immigrants who speak neither of these languages.

Comparisons are made to a study of immigrants in the 1983 Census of Israel, and immigrants in other countries. Estimates of the rate of return to the investment in language training are presented.

JEL Classification: J15, J 24, J31, J61

Keywords: Immigrants, Israel, Hebrew, earnings, language

Barry R. Chiswick

Department of Economics

University of Illinois at Chicago

601 South Morgan Street (m/c 144)

Chicago, IL 60607-7121, USA

Tel.: +1-312-996-2683

Fax: +1-312-996-3344

Email: brchis@uic.edu

\footnotetext{
*This paper is an outgrowth of Barry Chiswick's collaborative research with Paul W. Miller on the Economics of Language. This paper was presented at the Conference on the Economics of Judaism and Jewish Human Capital, cosponsored by the Departments of Economics at the University of Illinois at Chicago and Bar-Ilan University (Ramat Gan, Israel), held in Chicago, June 2000. Comments from Carmel U. Chiswick, Evelyn Lehrer, and Paul W. Miller on an earlier draft of this paper were very helpful. An earlier version of this paper was published in Sergio DellaPergola and Judith Evans, eds., Papers in Jewish Demography, 1997, Jerusalem: Hebrew University, Jewish Population Studies, 29 (2000). We appreciate the assistance of Michael Beenstock, Department of Economics, Hebrew University, and of Michal Peleg, Director, and Natasha Volchkima, both of the Social Science Data Archive, Hebrew University, in making available the 1972 Census of Israel.
} 


\section{Introduction}

This paper is concerned with an econometric analysis of the determinants of Hebrew language proficiency among adult male immigrants in Israel and the effect of this proficiency on the labor market earnings of these immigrants. The analysis is based on the 1972 Census of Israel and parallels an analysis performed for the 1983 Census (Chiswick, 1998). It is not possible to perform a similar analysis for the 1995 Census of Israel as this census did not include any questions on Hebrew language proficiency.

This study differs from analyses of language and earnings of immigrants in Israel performed using the various immigrant absorption surveys (see, for example, Beenstock 1993, 1996a, 1996b, Beenstock and Ben-Menahen 1997, Eckstein and Shackar 1995, Eckstein and Weiss 1998, Neuman 1998, and the references therein). The census contains a much larger sample size, and includes immigrants over a wide range of durations of residence and from all countries of origin, in contrast to the absorption surveys which have smaller samples, with limited duration in Israel (usually 3 or fewer years), and sometimes limited to specific origins (e.g., Jews from the former Soviet Union).

The motivation for this study is twofold. One is to develop even further and to sharpen the tests for the robustness of models for the acquisition by immigrants of the destination language and the effects of destination language skills on their earnings. Most such studies have been performed for the U.S., Canada and Australia, three highly developed, English-speaking countries of overseas settlement. English is an international language which may have value in the labor market even in the non-English speaking 
countries of origin. Are the models of language acquisition and impact also useful for a less well developed economy (Israel in 1972) in which the destination language is not English? Moreover, unlike the U.S., Canadian and Australian Censuses which ask only about speaking ability, the 1972 Census of Israel includes information on literacy in Hebrew, through a question on the ability to write in Hebrew, as well as on speaking Hebrew. ${ }^{1}$

Another motivation is to learn more about the immigrant absorption process in Israel. Israel expends considerable resources on Hebrew language training for new immigrants. What are the basic determinants of Hebrew language proficiency and what are the consequences for labor market earnings in the Israeli economy? The answers to these questions will provide insights that can guide immigration policy in countries that ration immigration visas on kinship, skill or refugee criteria, and can guide absorption (adjustment) policy in Israel and elsewhere.

Section 2 provides a thumbnail sketch of the language and earnings models. The details of these models are presented elsewhere. Section 3 provides a description of the variables in the 1972 Census of Israel that form the basis for this study. The empirical results are reported in Section 4. The paper closes with a summary and conclusion (Section 5). 


\section{The Models--Immigrant Language Acquisition and Earnings}

The theoretical models of immigrant acquisition of the destination language and immigrant earnings adjustment are presented here in thumbnail fashion as they have been developed elsewhere in detail. For the basic model development for earnings see Chiswick (1978) and for language, see Chiswick and Miller (1992, 1995), with an application of these approaches to Israel presented in Chiswick (1998).

\section{(a) Hebrew Language Proficiency}

The model of destination language proficiency among immigrants is based on a human capital framework. Language skills among immigrants are expected to be productive in the labor market and in consumption activities, are acquired at a sacrifice of time and out-of-pocket (direct) expenditures by the immigrant and those financing the immigrant's language acquisition, and these skills are embodied in the person. Therefore, language skills satisfy the three components of the definition of human capital.

The model of acquisition of dominant language proficiency is based on three conceptual explanatory variables: exposure, efficiency and economic factors. These three conceptual variables are discussed in turn with the development of variables to measure their influences.

Proficiency in Hebrew among immigrants in Israel is expected to be greater the more they are exposed to Hebrew. Exposure can be thought of as having three components: exposure prior to immigration, exposure measured in units of time in Israel, and exposure per unit of time in Israel.

The Census does not include any information on exposure to Hebrew prior to immigration. $^{2}$ Although country of birth is known, there is no country other than Israel in 
which Hebrew is a dominant language and most immigrants to Israel do not arrive with a working knowledge of the language. Some absorption surveys, however, do include information on pre-immigration knowledge of or study of Hebrew, and find that it enhances proficiency after immigration (see, for example, Beenstock 1996a).

Exposure in units of time is usually measured by duration of residence in the destination. It is typically measured as the number of years since the person first came to the destination as a permanent migrant. For most immigrants to Israel this is a one time event, although among North American immigrants there is a greater propensity for return migration that sometimes results in re-immigration. It is to be expected that the effect of duration on language skills is initially large and that the incremental effect on proficiency diminishes with duration of residence, suggesting a quadratic specification.

The intensity of exposure per unit of time in the destination is measured by several proxy variables. One is the ability to avoid using Hebrew, which is proxied by the extent to which others in the region in which the respondent lives speak the same non-Hebrew language as the respondent. The ability to avoid using Hebrew is greater if one speaks a language other than Hebrew that is common in the area (e.g., English) compared to a language that is rare (e.g., Greek).

The ability to avoid using Hebrew is also greater if one immigrates with a spouse who speaks the same origin language. This suggests that linguistic interactions within the household are important, and that proficiency would be lower among those whose current marriage was prior to immigration (married overseas). There is no particular hypothesis for the effect of being married after immigration in contrast to remaining single. 
Children, especially children born in Israel, may have partially offsetting impacts on parental proficiency. Parents may learn Hebrew from their Israeli-born or Israelieducated children. On the other hand, children would detract from parental acquisition of language skills if they serve as translators for their parents. Children as translators is likely to be more relevant for consumption activities than for labor market activities. ${ }^{3}$ Children also detract from parental destination language proficiency if the parents speak the origin language to preserve it among their children, or among women if children have an adverse effect on female labor supply. Previous research suggests that children born in the destination have a positive effect on the destination language proficiency of their fathers, but that the effect of children is less positive or more negative on their mother's language skills.

Efficiency in language acquisition refers to the process by which exposure is converted into destination language proficiency (human capital). Developmentally children are more efficient in language acquisition than are adults (Long 1990). It is expected that proficiency would fall with a rise in age at immigration. It is also expected that those with a higher level of schooling would be more proficient. ${ }^{4}$ Persons with more schooling may be more efficient (more able) learners; they would also have greater proficiency in their origin language and may have a greater understanding of the structure of languages.

Another factor relevant for the acquisition of destination language skills is the "linguistic distance" between that language and the origin languages. The closer are origin and destination languages, the greater the expected proficiency in the new destination language. Although a measure of linguistic distance between English and other languages 
has been developed and used successfully for the study of immigrants in the U.S. and Canada (Chiswick and Miller, 1998a), no comparable index has been developed for Hebrew. Yet some languages, such as Arabic, are linguistically closer to Hebrew than are other languages, such as English. Indeed, of all the major immigrant languages, Arabic is linguistically closest to Hebrew.

Labor market factors also effect the incentives to acquire destination language proficiency. Those who expect to receive higher wages if they were to become proficient have a greater incentive to become proficient. This is difficult to model empirically, and while sample selectivity tests have been performed on this proposition for Englishspeaking immigrant-receiving countries, this will not be done here, in part, because of the lack of identifying instruments (Chiswick and Miller 1992, 1995). It has also been shown elsewhere that immigrants with a higher level of schooling receive a larger increase in earnings from proficiency in the host language (Chiswick and Miller 1995). That is, it appears that schooling and language skills are complementary inputs in the generation of earnings. As a result, the education variable in the language equation will, in part, reflect the effect of greater economic benefits to the more educated to becoming proficient.

Immigrants to Israel from some countries have higher rates of emigrating, either to return to their origin or to go to a third country, than from others. The higher the probability of an immigrant leaving Israel, the shorter is the expected duration of residence, and given the country-specific nature of Hebrew, the weaker the incentive to invest in the language. Indeed, to the extent that immigrants to Israel from the U.S. and Canada have high propensities for return migration and immigrants from the Arab countries of North Africa and the Middle East have virtually no return migration, one 
would expect lesser fluency in Hebrew among the former than among the latter, other things being the same (Beenstock 1996b, Blejer and Goldberg 1980).

As a result of this discussion the analysis of Hebrew language proficiency for adult males is based on the following equation:

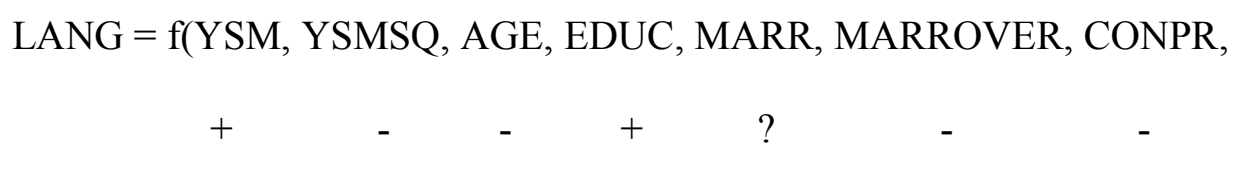

Children, Children born in Israel, Region of Residence, Country of Birth), ?

where LANG is a measure of proficiency in Hebrew, YSM, YSMSQ, AGE and EDUC denote years since migration and its square, age and educational attainment, respectively, while MARR and MARROVER are dichotomous variables that are unity for those currently married and those whose marriage occurred prior to immigration, respectively. CONPR is a language concentration measure. The actual measures of these variables available from the 1972 Census are discussed in Section 3. The hypothesized signs of the partial effects are indicated below the variables.

\section{(b) Earnings}

The modeling of the effect of Hebrew language skills on earnings is much more straight-forward. The approach uses the "human capital earnings function" which relates the natural logarithm of earnings to human capital (e.g., schooling and years of labor market experience) and demographic variables (e.g., gender, marital status, region of 
residence, etc.). It has been expanded to incorporate immigrant-related variables, including duration of residence, citizenship, country of origin, and of special interest here, destination language skills (Chiswick 1978, Chiswick and Miller 1995).

The earnings equation may be written as:

LNY = f(EDUC, EXP, EXPSQ, YSM, YSMSQ, MARR, LANG, CITIZ,

Region of residence, Country of Birth),

? $\quad$ ?

where LNY is the natural logarithm of earnings, EXP and EXPSQ are years of potential labor market experience and its square, CITIZ is a dichotomous variable for citizenship. ${ }^{5}$ The hypothesized signs are indicated below the explanatory variables.

\section{The Data - 1972 Census of Israel}

The data under study are the microdata sample created by the Central Bureau of Statistics from the 1972 Census of Israel. This is a 20 percent (one-in-five) simple random sample of the Israeli population. The data drawn from this sample for this study are limited to foreign-born Jewish men age 25 to 64 years in 1972 who were not enrolled in a Yeshiva in 1972. The age limits include the prime labor force years and are beyond the usual age of compulsory military service. Those enrolled in a Yeshiva are not labor market participants. The analysis is limited to males at this exploratory stage. 
The language questions in the 1972 Census are questions (11) and (12). Translated into English they are:

“11) Do you know how to write (at least a simple letter)?

a) Do you know how to write in Hebrew?

Yes, No

b) Do you know how to write in Arabic?

Yes, No

c) Do you know how to write in another language or languages? Yes, No

Respondents were not asked to specify the other languages in which they could write.

12) What is the language (or languages) that you speak every day?

Record the sole language or the primary language.

Record the second language.

Record the third language.

(Do not record languages that you know but do not speak every day)."

There is no information on the degree of literacy or the degree of fluency in spoken Hebrew. Literacy is expressed in this study as a dichotomous variable taking the value of unity for those who can write at least a simple letter in Hebrew, and zero otherwise (HEBWRIT). For speaking fluency four categories are considered: only speaks Hebrew (HEBONLY), speaks Hebrew as a primary but not only language (HEBPRIM), speaks it as a secondary or tertiary language (HEBSECTH), and does not speak Hebrew on a daily basis (HEBNONE). In some analyses the Hebrew fluency variable is dichotomous, where HEBSOP equals unity for those for whom it is the only or primary language spoken daily, and it is zero otherwise. 
The earnings variable is the gross annual salary for male wage and salary workers in Israeli Liras, the currency used in Israel at that time. The earnings analysis is performed only for those with positive earnings.

Most of the explanatory variables used in the analysis are fairly straightforward. Age (AGE) is measured in years since birth. Education (EDUC) is measured as years of schooling attended, with a top coding of 22 years. The maximum potential labor market experience is measured as age minus schooling minus five $(\mathrm{EXP}=\mathrm{AGE}-\mathrm{EDUC}-5)$, and is defined to equal zero for any negative values. Duration in Israel (YSM) is measured as the current year (1972) minus the year of "aliya" (immigration) to Israel.

Marital status (MARR) is unity for those who are currently married and zero otherwise. Married overseas (MARROVER) is unity for those in their first marriage if this took place prior to immigration (year of first marriage equal to or earlier than year of immigration), otherwise it is zero. The two children variables are a dichotomous variable equal to unity if there are children under age 20 living in the household (CHILDREN) and a dichotomous variable that equals unity if any of the married, widowed or divorced women living in the household has a child born in Israel (HCHILBIS).

The region of residence dichotomous variables are defined for Tel Aviv and Jerusalem, with the rest of the country as the benchmark. The various countries of birth are combined into seven regions: Asia (nearly all coming from the Asian countries of the Middle East), North Africa (from Morocco to Somalia), English-speaking countries (U.S., Canada, UK, Ireland, Australia, New Zealand, South Africa), Western Europe (other than the UK and Ireland), USSR and Latin America, with Eastern Europe (i.e., the post-war Communist bloc countries of Europe other than the USSR) as the benchmark. 
The language concentration measure (CONPR) is constructed in the following manner. The foreign-born adult male Jewish population is divided into the "natural regions" of the country. ${ }^{6}$ Within each region (i), the percentage of the group speaking each of the 12 most frequently reported only or primary languages other than Hebrew (j) is computed. $^{7}$ This percentage is the CONPR for each respondent in the region (i) reporting language (j) as their only or primary language. Thus, for a French speaker in Jerusalem the CONPR is the percent of foreign-born adult Jewish men in Jerusalem who speak French as their only or primary language. For those who speak only Hebrew, CONPR is defined to be zero since CONPR refers to the concentrations speaking languages other than Hebrew. It is also defined to equal zero for those reporting a primary language not in the top 12 languages other than Hebrew because the population density of these language speakers is so low.

\section{Empirical Analysis}

This section reports the statistical analysis of spoken Hebrew language usage and ability to write in Hebrew, followed by the statistical analysis of annual earnings among wage and salaried workers.

\section{a) Hebrew Language Proficiency}

The distribution of language skills among adult foreign-born Jewish men in Israel is reported in Table 10.1. Hebrew is the only language spoken on a daily basis among 24 percent of the men, for another 52 percent it is the primary but not the only language; for a total of 75 percent for whom it is the only or primary language. All told, including second and third languages reported, 89 percent report Hebrew as spoken daily. 
The second most frequently spoken language is Arabic, which is spoken primarily by North African and Middle Eastern immigrants. It is spoken by 5 percent of the Jewish immigrants as an only or primary language, but by 23 percent if second and tertiary languages are included. Yiddish, the traditional language of East European Jews, is in third place. English, an important international language, is spoken as the only or primary language of only one percent of the sample, but if second and third languages spoken are included, the proportion increases to 9 percent. The top 12 languages after Hebrew are spoken as the only or primary language by 22 percent of the adult foreign-born men, or by 88 percent of those reporting an only or primary language other than Hebrew.

There is a strong relation between duration in Israel and proficiency in Hebrew (Table 10.2). The proportion of foreign-born men reporting Hebrew as the only or primary language increases with duration in Israel. The pattern of improvement is similar to the one observed eleven years later in the 1983 Census (Chiswick 1998). ${ }^{8}$ This suggests that the pattern is not due to inherently poorer Hebrew language ability among the more recent cohorts of immigrants that would put them at a linguistic disadvantage throughout their life in Israel, but rather reflects a longitudinal effect-Hebrew language skills improving with duration of residence.

The means and standard deviations of the variables used in the analyses are reported in Table 10.3 by the degree of Hebrew usage. Those who are more proficient in Hebrew, that is, they speak it as their only or primary language, compared to those with lesser proficiency, tend to be younger, better educated, resided longer in Israel, were married in Israel and have children, with at least some children born in Israel. These are, however, simple relationships. 
The multiple regression analysis of spoken Hebrew language usage is reported in Table 10.4 using Ordinary Least Squares (OLS) and Logit analysis. Both procedures tell essentially the same story: Using Hebrew as the only or primary language is greater the higher the level of education, the longer the duration of residence, and the younger the age at immigration (age when duration in Israel is held constant). ${ }^{9}$ Those who married their current spouse prior to immigration are less likely to use Hebrew. The comparison of those who married after immigration with those not married shows an ambiguous pattern: lesser fluency for the former in the OLS analysis but no significant difference in the Logit analysis. Children, especially if born in Israel, are associated with a greater use of Hebrew among their fathers.

Compared to the rest of Israel, those living in the more religiously observant and traditional Jerusalem are more likely to use Hebrew as their only or primary language. Compared to the rest of Israel other than Jerusalem, Hebrew is less likely to play this role in Tel Aviv. Even after controlling for place of residence in Israel through the Tel Aviv/Jerusalem city variables, the linguistic concentration variable (CONPR) is statistically significant. That is, immigrants living in a region in which a larger proportion of the foreign born speak the same non-Hebrew language as the respondent are less likely to report they speak Hebrew as their only or primary language. This suggests that the greater the ease among immigrants to rely on their origin language, the less likely are they to use Hebrew.

Country of birth matters. Compared to Jewish immigrants born in Eastern Europe, those from North Africa and the Middle East (Asia) are more likely to use Hebrew as their only or primary language. These immigrants share with those of Eastern Europe a 
negligible propensity for return migration, but the language of their countries of origin (primarily Arabic) is linguistically closer to Hebrew then are the European languages. At the other extreme, those from Western Europe, and especially those from the Englishspeaking developed countries, have a much lower use of Hebrew. It is the immigrants from the English-speaking developed countries in particular that have a high degree of return migration (see, Beenstock 1996b and Blejer and Goldberg 1980). Indeed, Hebrew usage by country of origin seems to be greater the lower degree of return migration and the closer the language of the origin is to Hebrew.

There is a strong relationship between Hebrew speaking frequency and ability to write in Hebrew, but the correlation is far from perfect. ${ }^{10}$ Table 10.5 reports the OLS and logit analysis of the determinants of being able to write (a simple letter) in Hebrew. The patterns are generally the same as for speaking. Those with more schooling, who have been in Israel a longer period of time, who immigrated at a younger age, who did not marry prior to immigration, and who have children, especially children born in Israel, are more likely to be able to write a letter in Hebrew. Those who live in Jerusalem are more likely to be able to write in Hebrew in the logit analysis, but there is no difference between Tel Aviv and the rest of the country. Those who live in areas where more immigrants speak their origin language (CONPR) are less able to write in Hebrew.

Country of origin also matters for writing, with the patterns being similar to that for speaking. Those from North Africa and the Middle East have a greater propensity to be able to write in Hebrew, compared to Eastern European immigrants, even though the Arabic alphabet is very different than the Hebrew alphabet. Those from Western Europe 
and the English-speaking countries are less able to write in Hebrew than Eastern European immigrants.

Although the dependent variables are not strictly comparable, and the general patterns are very similar, there are some interesting differences in the partial effects of some of the explanatory variables on speaking and writing Hebrew. Education has a much larger impact on writing skills than on speaking, whereas duration in Israel has a larger impact on improving speaking than on improving writing. The negative impact on Hebrew proficiency of the linguistic concentration measure is stronger for speaking than for writing. These patterns for the differential effect on speaking and writing of these explanatory variables are remarkably similar to what was found in a study of English speaking and reading proficiency among illegal aliens who obtained legal status (primarily of Hispanic origin) in the United States (Chiswick and Miller 1999). This provides additional support for the robustness of the findings within and across countries. The comparison with the U.S. study also suggests very similar determinants of the two dimensions of literacy, reading and writing skills.

As a further refinement of the analysis, Table 10.6 reports the multinomial logit analysis of the four category Hebrew variable: Only Hebrew, Hebrew primary, Hebrew secondary (or tertiary) and No Hebrew spoken daily. ${ }^{11}$ Although the signs and levels of statistical significance are indicated in Table 10.6, the magnitudes can be difficult to interpret. To facilitate interpretation, Table 10.7 reports the probabilities that an individual with a particular set of characteristics will be in each of the four language groups, based on the multinomial logit analysis in Table 10.6. The probabilities in a row sum to unity. 
The top row of Table 10.7 reports the probabilities for the person with "mean" characteristics, while the second row reports the probabilities for the base or reference person. The base or reference person in Table 10.7 has a mean age (age 44.6 ), level of education (9.1 years), and duration in Israel (21.1 years), is married, but married after immigration, and has children that were born in Israel. The reference person was born in Western Europe and does not live in Jerusalem or Tel Aviv.

The analysis indicates that the probability of speaking only Hebrew or speaking Hebrew as a primary language increases with education. The probability of speaking Hebrew as the only or primary language increases from 83 percent for those with base characteristics and 10 years of schooling to 90 percent for those with 15 years of schooling. Although the probability of speaking Hebrew as a primary but not only language decreases from 61 percent to 55 percent from 16 to 38 years duration in Israel, the probability that it is the only language spoken daily increases from 11 percent to 41 percent. The effect of an older age at migration on speaking Hebrew (the age variable for the base duration in Israel) is dramatic; Hebrew usage is lower the older the age at migration.

Those who married overseas are less likely to speak only Hebrew or to speak it as a primary language. Not having children or having children who were not born in Israel is associated with lesser use of Hebrew.

The analysis also shows important differences by country of origin. Immigrants from English-speaking countries are much more likely to report Hebrew as their second (or third) language spoken or that they speak no Hebrew. English is presumably being predicted as the primary or only language spoken on a daily basis by 34 percent of those 
from English-speaking countries (28.5 percent speak Hebrew as the second or third language and 5.5 percent do not speak Hebrew on a daily basis).

\section{b) Earnings}

The mean annual earnings of wage and salary workers in 1972 in Israeli Liras are reported in Table 10.8 for adult Jewish immigrants by Hebrew speaking and writing proficiencies. ${ }^{12}$ These simple relationships show that for each level of speaking Hebrew, earnings are higher for those who can write in Hebrew. For each writing level, earnings are higher for those who speak Hebrew as their only or primary language, compared to those for whom it is a second or third language or who do not speak Hebrew. The highest earnings are received by those for whom Hebrew is the primary language, but they also speak another language on a daily basis, and they can write a letter in Hebrew (IL 12,518). The lowest earnings are received by those who neither speak Hebrew on a daily basis, nor can they write in Hebrew (IL 8,045).

The statistical analysis of earnings is reported in Tables 10.9 and 10.10 to ascertain the effects of Hebrew speaking usage and Hebrew literacy, when other variables are held constant. Table 10.9 column (1) reports the basic earnings equation without the language variables, while speaking skills are added in the next three columns. In Table 10.10 the effects on earnings are examined for writing skills and for speaking and writing combined.

The effects of the basic variables on earnings are largely invariant with respect to the inclusion of speaking and writing variables. Earnings increase with additional human capital (Table 10.9, column 1). Earnings increase by about 4 percent per year of schooling (EDUC) which is lower than the 6 percent found in the analysis of immigrants in the 1983 Census, as well as lower than in the United States and Canada. 
Earnings increase with pre-immigration labor market experience (EXP), at about 1.8 percent per year when evaluated at 10 years of experience. Experience in Israel (YSM) has a larger effect. Evaluated at 10 years, the effect of an extra year in Israel on earnings rather than an extra year in the country of birth is 2.1 percent when language skills are not held constant and about 1.7 percent when they are. Some of the effect of duration in Israel on earnings operates through language skills, that is, Hebrew language proficiency increases with duration and greater proficiency enhances earnings. Married men earn considerably more than observationally similar men who are not married. These patterns are similar to effects found in the 1983 Census and for other immigrant receiving countries.

Place of residence in Israel matters. Earnings are about 5 percent lower in Jerusalem and 1.6 percent lower in Tel Aviv than in the rest of the country (Table 10.9, column 1). This is slightly different from the pattern in the 1983 Census, an 8 percent lower earnings in Jerusalem and no significant difference in earnings in Tel Aviv. More striking is the difference between Israel, on the one hand, and the U.S. and Canada on the other, where earnings tend to increase with population density or city size.

Country of birth also matters. Compared to immigrants from Eastern Europe, earnings are lower by about 20 percent among those from Asia (Middle East), 14 percent among those from North Africa, and 11 percent among those from the USSR (Table 10.9, column 1). There is no significant difference in earnings between Western European and Eastern European origin immigrants. Some immigrants, on the other hand, have earnings significantly higher than Eastern Europeans-about 20 percent higher for those from 
English-speaking developed countries and 7 percent higher among Latin American immigrants.

When the language variables are added to the earnings equation it is clear that Hebrew language skills matter. Speaking only Hebrew or speaking it as a primary language raises earnings by about 13 percent (Table 10.9, column 2). Compared to those who speak only Hebrew, there is no difference in earnings on the part of those who speak it as a primary language, but earnings are lower by about 9 percent for those who report it as a second or tertiary language, and by over 20 percent for those who do not speak it on a daily basis (Table 10.9, column 3 ).

Other variables the same, speaking English on a daily basis is associated with about 15 percent higher earnings (Table 10.9, column 4). ${ }^{13}$ On the other hand, speaking Arabic is associated with about 2 percent lower earnings. These patterns are very similar to the earnings differences for English and Arabic speakers in the 1983 Census (Chiswick, 1998). Greater earnings for English language skills, even when country of origin is held constant, may arise because English is an international language. ${ }^{14}$ Those engaged in foreign trade or in tourism in Israel may have expanded opportunities if they have some degree of proficiency in English. Moreover, immigrants from the high income English-speaking developed countries have a high opportunity cost of remaining in Israel and a high propensity for return migration. Perhaps mainly those who "do well" in Israel remain.

Harder to explain are the lower earnings of those who speak Arabic on a daily basis, even after controlling for country of origin. Jewish immigrants from the Middle East and North Africa who speak Arabic on a daily basis may be less well skilled in 
Hebrew and less integrated into the mainstream Israeli economy, than those who do not speak Arabic, other things being the same.

The analysis of literacy indicates that those who can write a letter in Hebrew earn about 12 percent more than those who cannot (Table 10.10, column 1). When Hebrew speaking and writing are both included in the analysis, each is statistically significant (Table 10.10, columns 2 and 3). Of particular note is Table 10.10, column (4). The benchmark is those for whom Hebrew is the only or primary language and who can write a simple letter in Hebrew. Those who can speak Hebrew but not write it have 8 percent lower earnings (YSPNWR). Those who do not speak Hebrew as an only or primary language but who can write Hebrew (NSPYWR) have 10 percent lower earnings. While those who neither speak nor write Hebrew (NSPNWR) have 20 percent lower earnings.

The analysis of earnings indicates that the skills of immigrants matter. Earnings increase with schooling and pre-immigration labor market experience. Post-immigration labor market experience and both speaking and writing Hebrew language skills are also important determinants of earnings. Earnings also vary by origin, with North African and Middle Eastern Jewish immigrants having the lowest earnings, perhaps because of the lower quality of schooling in their origins and their pre-immigration human capital was formed in economies at a much lower level of economic development than was Israel in 1972. Immigrants from the English-speaking developed countries have the highest earnings, in part because they speak the most important international language, come from highly developed economies with advanced school systems, and the high wages, political freedom and absence of persecution in their origin countries means that they have a high opportunity cost of staying in Israel. The high propensity for return migration and the 
high opportunity cost of staying is Israel may account for the high earnings of the immigrants from English-speaking countries that remain in Israel.

It is possible to estimate the rate of return on the investment in Hebrew language proficiency. It was found here that, at least in 1972, proficiency in Hebrew increased earnings by 20 percent, all other variables being the same. Suppose that this level of Hebrew proficiency can be obtained through a six month full time intensive Hebrew language ("ulpan") training program. The cost of this program is the foregone earnings plus the costs of the teachers, classroom, supplies, etc. For simplicity of exposition let us assume that these latter costs are also equal to six months forgone earnings. If the total cost is the equivalent of a full year's potential earnings and if a long work life is assumed (and 30 years would be sufficiently long), the real social rate of return on this investment would be approximately 20 percent. ${ }^{15}$ This would be a high rate of return on an investment in human capital. The rate of return would, of course, be lower if the immigrant is older (shorter remaining working life) or if the immigrant requires a longer or more expensive training period, and would be higher if the training costs were lower than what was used in this example.

\section{Summary and Conclusions}

This study has used the 1972 Census of Israel to analyze the determinants of Hebrew speaking and writing proficiency among adult male Jewish immigrants. It also analyzes the effects of these skills on labor market earnings.

Hebrew speaking proficiency is measured by whether it is spoken on a daily basis as the only language or in conjunction with other languages, or not at all. Writing proficiency is measured by the ability to write a letter in Hebrew. The analysis 
demonstrates that the acquisition of these skills is consistent with the model of immigrant language acquisition developed for English-speaking destinations. In particular, Hebrew language proficiency among adult male immigrants is greater among those who: immigrated at a younger age, have been in Israel longer, and have more schooling. Hebrew skills are lower among those who married their current wife prior to immigration, and are greater among those with children, especially if they were born in Israel. Thus, skills and family structure matter.

Hebrew language skills are associated with where one lives in Israel. Those living in Tel Aviv are less likely to speak Hebrew, while those living in Jerusalem are more likely to speak and write Hebrew than immigrants living in the rest of the country. Those living in areas where many others use their origin language are less likely to speak Hebrew or to be able to write in Hebrew. That is, linguistic concentrations or enclaves retard Hebrew language acquisition.

Immigrants from North Africa and the Middle East show the greatest use of Hebrew, perhaps because it is linguistically close to Arabic and they have a low propensity for return migration. Those from Western Europe, and especially those from the developed English-speaking countries, have the least proficiency in Hebrew. The high propensity for return migration and the importance of English as an international language may discourage English language speakers from investing in the Hebrew language.

Hebrew language skills influence earnings. Those who speak Hebrew as an only or primary language earn about 13 percent more per year than those who use it less frequently or not at all, while those who can write in Hebrew have a similar earnings advantage. Although they are related, Hebrew speaking and writing proficiency have separate effects 
and both matter. Those who possess both skills earn about 20 percent more than those who lack both skills.

Hebrew is not the only language that effects earnings. Immigrants who speak English have an earnings advantage of about 16 percent, while those who speak Arabic have a 2 percent earnings disadvantage, other variables being the same.

The similarity of the findings with other immigrant receiving countries suggests that the underlying processes determining Hebrew language usage in Israel and its effect on earnings are the same as elsewhere. The large effects on earnings of Hebrew language skills indicates its importance in the labor market and for the successful absorption of immigrants. 


\section{References}

Beenstock, Michael (1993) "Learning Hebrew and Finding a Job: Econometric Analysis of Immigrant Absorption in Israel" Falk Institute, Hebrew University, Jerusalem. Discussion Paper No. 93.05.

Beenstock, Michael (1996a) "The Acquisition of Language Skills by Immigrants: The Case of Hebrew in Israel" International Migration, 34(1), pp. 3-30.

Beenstock, Michael (1996b) "Failure to Absorb: Remigration by Immigrants to Israel" International Migration Review, 30(4), pp. 950-978.

Beenstock, Michael and Yitzhak Ben-Menahem (1997) “The Labor Market Experience of CIS Immigrants to Israel: 1989-1994” International Migration, 35(2), pp. 187224.

Blejer, Mario I. And Itzhak Goldberg (1980) "Return Migration-Expectations versus Reality: A Case Study of Western Immigrants in Israel” Research in Population Economics, Vol. 2, pp. 443-449.

Chiswick, Barry R. (1978) "The Effect of Americanization on the Earnings of ForeignBorn Men," Journal of Political Economy, 86(5), October, pp. 897-922. 
Chiswick, Barry R. (1991) "Speaking, Reading and Earnings Among Low-Skilled Immigrants" Journal of Labor Economics, 9(2), April, pp. 149-170.

Chiswick, Barry R. (1998) “Hebrew Language Usage: Determinants and Effects on Earnings Among Immigrants in Israel” Journal of Population Economics, 11(2), pp. $253-271$.

Chiswick, Barry R. and Paul W. Miller (1992) "Language in the Immigrant Labor Market" in Barry R. Chiswick, ed. Immigration, Language and Ethnicity: Canada and the United States, Washington: American Enterprise Institute, pp. 229-296, 471-476.

Chiswick, Barry R. and Paul W. Miller (1995) "The Endogeneity Between Language and Earnings: International Analyses," Journal of Labor Economics, 13(2), April, pp. $245-287$.

Chiswick, Barry R. and Paul W. Miller (1998a) “English Language Fluency Among Immigrants in the United States" Research in Labor Economics, Vol 17, pp. 151200.

Chiswick, Barry R. and Paul W. Miller (1998b) "Language Skill Definition: A Study of Legalized Aliens" International Migration Review, 32(4) Winter, pp. 877-900. 
Chiswick, Barry R. and Paul W. Miller (1999) “Language Skills and Earnings Among Legalized Aliens" Journal of Population Economics, 12(1) February, pp. 63-91.

Dustmann, Christian, (1994) "Speaking Fluency, Writing Fluency and Earnings of Migrants" Journal of Population Economics, 7(2), pp. 133-156.

Eckstein, Zvi and Ron Shachar (1995) “On the Transition to Work of New Immigrants: Israel 1990-92,” Department of Economics, Tel Aviv University, mimeo.

Eckstein, Zvi and Yoram Weiss (1998) “The Absorption of Highly Skilled Immigrants: Israel, 1990-1995” Department of Economics, Tel Aviv University, February 5, 1998.

Friedberg, Rachel (2000) "You Can't Take it With You? Immigrant Assimilation and the Portability of Human Capital" Journal of Labor Economics, 18(2), April, pp. 221-251 .

Hedges, Chris (2000) "Translating America for Parents and Family" New York Times, Monday, June 19, New York Report, p. A19 (Midwest Edition). 
Kee, Peter (1993) The Economic Status of Male Immigrants in the Netherlands, Amsterdam: University of Amsterdam.

Long, Michael H. (1990) “Maturational Constraints on Language Development” Studies in Second Language Acquisition, 12(3), pp. 251-285.

Neuman, Shoshana (1998) "Immigration: The Israeli Case" Department of Economics, Bar Ilan University, Ramat Gan, Israel, xerox.

Raijman, Rebeca and Moshe Semyonov (1998) "Best of Times, Worst of Times, and Occupational Mobility: the Case of Russian Immigrants in Israel” Research on Immigration and Integration in the Metropolis, Vancouver, Working Paper, 9804.

Rivera-Batiz, Francisco L. (1996) “English Language Proficiency, Quantitative Skills, and the Economic Progress of Immigrants" in Harriet Orcutt Duleep and Phanindra V. Wunnava, eds. Immigrants and Immigration Policy: Individual Skills, Family Ties, and Group Identities, Greenwich: JAI Press, pp. 57-77. 
Table 10.1

FREQUENCY DISTRIBUTION OF LANGUAGES SPOKEN ISRAEL, 1972

(Foreign-Born Jewish Men, Age 25 to 64)

\begin{tabular}{lccc}
\hline Language & $\begin{array}{c}\text { Only } \\
\text { and } \\
\text { Primary }\end{array}$ & $\begin{array}{c}\text { Only } \\
\text { Primary } \\
\text { and Second }\end{array}$ & $\begin{array}{c}\text { Only } \\
\text { Primary, Second } \\
\text { and Third }\end{array}$ \\
\hline Hebrew & 75.4 & 86.5 & 88.9 \\
Arabic & 4.8 & 20.0 & 22.9 \\
Yiddish & 4.0 & 14.3 & 17.7 \\
Romanian & 3.4 & 8.4 & 9.9 \\
French & 1.9 & 7.7 & 10.7 \\
Spanish-Ladino & 1.6 & 4.9 & 6.0 \\
English & 1.3 & 5.4 & 8.6 \\
Hungarian & 1.1 & 3.3 & 4.1 \\
Kurdish & 0.9 & 1.8 & 2.1 \\
Russian & 0.8 & 2.0 & 3.0 \\
German & 0.8 & 3.9 & 5.9 \\
Persian & 0.7 & 2.2 & 2.3 \\
Polish & 0.7 & 3.2 & 5.2 \\
Other & 2.9 & 2.3 & 2.2 \\
TOTAL & & & (b) \\
\hline \hline
\end{tabular}

Note: Sample Size: 92,797

(a) Hebrew is the only language spoken by 23.7 percent.

(b) Column adds to more than 100 percent due to dual and triple language fluency.

Source: 1972 Census of Population and Housing, Israel, Public Use Sample, Demographic File, 20 percent sample of the population. 
Table 10.2

HEBREW SPEAKING SKILLS BY DURATION IN ISRAEL

(Foreign-Born Jewish Men, Age 25 to 64, Israel, 1972)

\begin{tabular}{|c|c|c|c|c|c|c|c|}
\hline \multirow[b]{2}{*}{$\begin{array}{l}\text { Duration } \\
\text { (Years) }\end{array}$} & \multirow[b]{2}{*}{$\begin{array}{l}\text { Sample } \\
\text { Size }\end{array}$} & \multicolumn{6}{|c|}{$\begin{array}{c}\text { Hebrew Language Skills } \\
\text { (percent) }\end{array}$} \\
\hline & & $\begin{array}{c}\text { Only } \\
\text { Lang. }\end{array}$ & $\begin{array}{l}\text { Primary } \\
\text { Lang. }\end{array}$ & $\begin{array}{c}\text { Second + } \\
\text { Third } \\
\text { Lang. }\end{array}$ & $\begin{array}{c}\text { Does } \\
\text { Not } \\
\text { Speak }\end{array}$ & Unknown & Total \\
\hline $0-5$ & 5,799 & 3.22 & 21.54 & 31.63 & 39.14 & 4.47 & 100.00 \\
\hline $6-10$ & 9,377 & 8.37 & 43.50 & 25.10 & 20.65 & 2.38 & 100.00 \\
\hline $11-15$ & 8,858 & 12.10 & 49.73 & 21.64 & 14.41 & 2.12 & 100.00 \\
\hline $16-20$ (a) & 8,043 & 21.19 & 55.94 & 13.96 & 6.39 & 2.52 & 100.00 \\
\hline $21-25$ & 42,582 & 27.46 & 55.38 & 10.56 & 4.64 & 1.97 & 100.00 \\
\hline $26-30$ & 4,574 & 33.95 & 59.93 & 5.18 & 2.32 & 1.62 & 100.00 \\
\hline $31-35$ & 3,831 & 31.66 & 59.07 & 5.69 & 2.01 & 1.57 & 100.00 \\
\hline Over 35 & 9,733 & 38.42 & 54.43 & 3.82 & 1.80 & 1.53 & 100.00 \\
\hline Total & 92,797 & 23.65 & 51.70 & 13.52 & 8.97 & 2.15 & 100.00 \\
\hline
\end{tabular}

(a) These immigrants arrived in 1947 to 1951, encompassing the year of independence and the subsequent large immigration from Europe, North Africa and the Middle East.

Source: 1972 Census of Population and Housing, Israel, Public Use Sample, Demographic File, 20 percent sample of the population. 
Table 10.3

MEANS AND STANDARd DEVIATIONS OF VARIABLES USED IN LANGUAGE ANALYSIS, ISRAEL, 1972 (Foreign-Born Jewish Men, Age 25 to 64, Israel, 1972)

\begin{tabular}{|c|c|c|c|c|c|}
\hline Variable & All & $\begin{array}{c}\text { Hebrew } \\
\text { Only }\end{array}$ & $\begin{array}{l}\text { Hebrew } \\
\text { primary }\end{array}$ & $\begin{array}{l}\text { Hebrew } \\
\text { second or } \\
\text { third }\end{array}$ & No Hebrew \\
\hline \multirow[t]{2}{*}{ AGE } & 44.63 & 41.08 & 44.09 & 49.00 & 51.25 \\
\hline & (11.63) & $(11.51)$ & $(11.29)$ & (10.64) & (10.39) \\
\hline \multirow[t]{2}{*}{ EDUC } & 9.09 & 9.65 & 9.49 & 8.04 & 7.02 \\
\hline & $(4.45)$ & $(4.04)$ & $(4.21)$ & $(5.01)$ & $(4.92)$ \\
\hline \multirow[t]{2}{*}{ YSM } & 21.14 & 25.19 & 22.29 & 15.87 & 12.35 \\
\hline & $(9.81)$ & $(8.82)$ & $(8.96)$ & $(9.02)$ & $(9.31)$ \\
\hline \multirow[t]{2}{*}{ YSMSQ } & 543.00 & 712.53 & 576.89 & 333.34 & 239.10 \\
\hline & $(466.97)$ & $(513.69)$ & $(453.38)$ & $(331.32)$ & $(317.08)$ \\
\hline \multirow{2}{*}{ MARR } & 0.90 & 0.90 & 0.91 & 0.92 & 0.89 \\
\hline & $(0.30)$ & $(0.30)$ & $(0.29)$ & $(0.27)$ & $(0.32)$ \\
\hline \multirow[t]{2}{*}{ MARROVER } & 0.37 & 0.16 & 0.33 & 0.71 & 0.79 \\
\hline & $(0.48)$ & $(0.36)$ & $(0.47)$ & $(0.45)$ & $(0.41)$ \\
\hline \multirow[t]{2}{*}{ CHILDREN } & 0.68 & 0.74 & 0.72 & 0.61 & 0.48 \\
\hline & $(0.47)$ & $(0.44)$ & $(0.45)$ & $(0.49)$ & $(0.50)$ \\
\hline \multirow[t]{2}{*}{ HCHILBIS } & 0.69 & 0.81 & 0.76 & 0.52 & 0.32 \\
\hline & $(0.46)$ & $(0.39)$ & $(0.43)$ & $(0.50)$ & $(0.47)$ \\
\hline \multirow[t]{2}{*}{ TEL-AVIV } & 0.35 & 0.39 & 0.36 & 0.31 & 0.30 \\
\hline & $(0.48)$ & $(0.49)$ & $(0.48)$ & $(0.46)$ & $(0.46)$ \\
\hline \multirow[t]{2}{*}{ JERUSALEM } & 0.07 & 0.07 & 0.08 & 0.07 & 0.04 \\
\hline & $(0.26)$ & $(0.26)$ & $(0.26)$ & $(0.25)$ & $(0.21)$ \\
\hline \multirow[t]{2}{*}{ ASIA } & 0.21 & 0.30 & 0.21 & 0.15 & 0.11 \\
\hline & $(0.41)$ & $(0.46)$ & $(0.41)$ & $(0.35)$ & $(0.31)$ \\
\hline \multirow{2}{*}{ NORTHAFR } & 0.23 & 0.19 & 0.24 & 0.26 & 0.22 \\
\hline & $(0.42)$ & $(0.40)$ & $(0.43)$ & $(0.44)$ & $(0.42)$ \\
\hline \multirow[t]{2}{*}{ USSR } & 0.06 & 0.06 & 0.05 & 0.05 & 0.12 \\
\hline & $(0.23)$ & $(0.25)$ & $(0.21)$ & $(0.22)$ & $(0.32)$ \\
\hline \multirow[t]{2}{*}{ EASTEURO } & 0.41 & 0.37 & 0.41 & 0.44 & 0.48 \\
\hline & $(0.49)$ & $(0.48)$ & $(0.50)$ & $(0.50)$ & $(0.50)$ \\
\hline \multirow[t]{2}{*}{ WESTEURO } & 0.06 & 0.06 & 0.06 & 0.05 & 0.03 \\
\hline & $(0.23)$ & $(0.24)$ & $(0.24)$ & $(0.21)$ & $(0.18)$ \\
\hline \multirow[t]{2}{*}{ ENGLSPEA } & 0.01 & 0.005 & 0.01 & 0.04 & 0.02 \\
\hline & $(0.12)$ & $(0.07)$ & $(0.10)$ & $(0.20)$ & $(0.15)$ \\
\hline \multirow[t]{2}{*}{ LATIAMER } & 0.01 & 0.005 & 0.02 & 0.02 & 0.02 \\
\hline & $(0.12)$ & $(0.08)$ & $(0.12)$ & $(0.13)$ & $(0.14)$ \\
\hline \multirow[t]{2}{*}{ CONPR } & 10.19 & 0 & 13.62 & 14.07 & 13.84 \\
\hline & $(10.18)$ & $(0)$ & $(9.42)$ & $(9.76)$ & $(9.83)$ \\
\hline SAMPLE SIZE & 92,797 & 21,947 & 47,977 & 12,550 & 8,328 \\
\hline
\end{tabular}

Note: The variables are defined in the text.

Source: 1972 Census of Population and Housing, Israel, Public Use Sample, Demographic File, 20 percent sample of the population. 
Table 10.4

ANALYSIS OF DETERMINANTS OF SPEAKING HEBREW USED AS ONLY OR

Primary LaNguage, ISRAEL, 1972

(Foreign-Born Jewish Men, Age 25 to 64)

\begin{tabular}{|c|c|c|}
\hline VARIABLES & $\begin{array}{c}\text { OLS } \\
(1)\end{array}$ & $\begin{array}{c}\text { LOGIT } \\
(2)\end{array}$ \\
\hline \multirow[t]{2}{*}{ CONSTANT } & 0.4544 & 0.0769 \\
\hline & $(47.67)$ & {$[0.96]$} \\
\hline \multirow[t]{2}{*}{ AGE } & -0.0073 & -0.0595 \\
\hline & $(-47.41)$ & {$[-42.59]$} \\
\hline \multirow[t]{2}{*}{ EDUC } & 0.0142 & 0.1137 \\
\hline & $(45.53)$ & {$[42.25]$} \\
\hline \multirow[t]{2}{*}{ YSM } & 0.0339 & 0.2022 \\
\hline & $(77.70)$ & [51.25] \\
\hline \multirow[t]{2}{*}{ YSMSQ } & -0.0004 & -0.0019 \\
\hline & $(-44.94)$ & {$[-21.52]$} \\
\hline \multirow[t]{2}{*}{ MARR } & -0.0190 & 0.0139 \\
\hline & $(-4.10)$ & {$[0.35]$} \\
\hline \multirow{2}{*}{ MARROVER } & -0.0716 & -0.4560 \\
\hline & $(-20.20)$ & {$[-15.81]$} \\
\hline \multirow[t]{2}{*}{ CHILDREN } & 0.0262 & 0.3125 \\
\hline & $(7.80)$ & [11.16] \\
\hline \multirow[t]{2}{*}{ HCHILBIS } & 0.0755 & 0.2811 \\
\hline & $(21.04)$ & {$[9.88]$} \\
\hline \multirow[t]{2}{*}{ TEL-AVIV } & -0.0080 & -0.0776 \\
\hline & $(-3.00)$ & {$[-3.23]$} \\
\hline \multirow[t]{2}{*}{ JERUSALEM } & 0.0143 & 0.1522 \\
\hline & (2.99) & {$[3.41]$} \\
\hline \multirow[t]{2}{*}{ ASIA } & 0.0556 & 0.4876 \\
\hline & $(15.87)$ & [14.88] \\
\hline \multirow[t]{2}{*}{ NORTHAFR } & 0.0809 & 0.6203 \\
\hline & $(23.01)$ & [20.17] \\
\hline \multirow[t]{2}{*}{ USSR } & 0.0012 & 0.0392 \\
\hline & $(0.21)$ & {$[0.76]$} \\
\hline \multirow[t]{2}{*}{ WESTEURO } & -0.0671 & -0.6127 \\
\hline & $(-12.23)$ & {$[-11.56]$} \\
\hline \multirow[t]{2}{*}{ ENGLSPEA } & -0.1703 & -1.2923 \\
\hline & $(-16.25)$ & {$[-16.93]$} \\
\hline \multirow[t]{2}{*}{ LATIAMER } & 0.0552 & 0.0734 \\
\hline & $(5.27)$ & {$[0.90]$} \\
\hline \multirow[t]{2}{*}{ CONPR } & -0.0035 & -0.0307 \\
\hline & $(-28.02)$ & {$[-28.32]$} \\
\hline $\mathbf{R}^{2}$ adj. & 0.3339 & \\
\hline Chi Square & & $28,299.44$ \\
\hline Sample Size & 81,594 & 81,594 \\
\hline
\end{tabular}

Dependent variable: $\mathrm{HEBSOP}=1$ if speak Hebrew as only or primary language, otherwise it is zero. $t$ ratios are in parentheses.

Asymptotic t ratios are in brackets.

Source: 1972 Census of Population and Housing, Israel, Public Use Sample, Demographic File, 20 percent sample of the population. 
Table 10.5

ANALYSIS OF DETERMiNANTS OF HEBREW WRITING, ISRAEL, 1972

(Foreign-Born Jewish Men, Age 25 to 64)

\begin{tabular}{|c|c|c|}
\hline VARIABLES & $\begin{array}{l}\text { OLS } \\
\text { (1) }\end{array}$ & $\begin{array}{c}\text { LOGIT } \\
\text { (2) }\end{array}$ \\
\hline \multirow[t]{2}{*}{ CONSTANT } & 0.4164 & -1.2570 \\
\hline & $(48.41)$ & {$[-13.39]$} \\
\hline \multirow{2}{*}{ AGE } & -0.0051 & -0.0468 \\
\hline & $(-36.22)$ & [-29.34] \\
\hline \multirow[t]{2}{*}{ EDUC } & 0.0339 & 0.3186 \\
\hline & (120.36) & [92.79] \\
\hline \multirow[t]{2}{*}{ YSM } & 0.0195 & 0.1488 \\
\hline & $(49.46)$ & [32.82] \\
\hline \multirow[t]{2}{*}{ YSMSQ } & -0.0002 & -0.0012 \\
\hline & $(-27.19)$ & {$[-10.86]$} \\
\hline \multirow[t]{2}{*}{ MARR } & 0.0104 & 0.2023 \\
\hline & $(2.49)$ & [4.37] \\
\hline \multirow{2}{*}{ MARROVER } & -0.0408 & -0.3965 \\
\hline & $(-12.71)$ & {$[-11.69]$} \\
\hline \multirow[t]{2}{*}{ CHILDREN } & 0.0010 & 0.2172 \\
\hline & $(3.28)$ & [6.65] \\
\hline \multirow[t]{2}{*}{ HCHILBIS } & 0.0453 & 0.2309 \\
\hline & $(13.95)$ & {$[6.91]$} \\
\hline \multirow[t]{2}{*}{ TEL-AVIV } & 0.0033 & 0.0008 \\
\hline & $(1.36)$ & {$[0.03]$} \\
\hline \multirow[t]{2}{*}{ JERUSALEM } & -0.0041 & 0.1277 \\
\hline & $(-0.95)$ & {$[2.45]$} \\
\hline \multirow[t]{2}{*}{ ASIA } & 0.0237 & 0.3574 \\
\hline & $(7.48)$ & {$[9.65]$} \\
\hline \multirow[t]{2}{*}{ NORTHAFR } & 0.0347 & 0.4277 \\
\hline & $(10.91)$ & [12.17] \\
\hline \multirow{2}{*}{ USSR } & -0.0165 & 0.0568 \\
\hline & $(-3.30)$ & {$[0.96]$} \\
\hline \multirow[t]{2}{*}{ WESTEURO } & -0.0533 & -0.3764 \\
\hline & $(-10.78)$ & {$[-5.31]$} \\
\hline \multirow[t]{2}{*}{ ENGLSPEA } & -0.0170 & -0.5139 \\
\hline & $(-1.799)$ & {$[-4.65]$} \\
\hline \multirow[t]{2}{*}{ LATIAMER } & 0.0303 & 0.1167 \\
\hline & $(3.22)$ & {$[1.06]$} \\
\hline \multirow[t]{2}{*}{ CONPR } & -0.0005 & -0.0038 \\
\hline & $(-4.47)$ & {$[-3.11]$} \\
\hline $\mathrm{R}^{2}$ adj. & 0.3077 & \\
\hline Chi Square & & $26,293.33$ \\
\hline Sample Size & 81,025 & 81,025 \\
\hline
\end{tabular}

Dependent variable: HEBWRIT=1 if know how to write at least a simple letter in Hebrew, otherwise it is zero.

$\mathrm{t}$ ratios are in parentheses.

Asymptotic $t$ ratios are in brackets.

Source: 1972 Census of Population and Housing, Israel, Public Use Sample, Demographic File, 20 percent sample of the population. 
Table 10.6

Multinomial Logit Analysis of Hebrew Language USAge, Israel, 1972

(Foreign-Born Jewish Men, Age 25 to 64)

\begin{tabular}{|c|c|c|c|}
\hline Variable & $\begin{array}{c}\text { Primary Lang. } \\
\text { relative to } \\
\text { Only Hebrew }\end{array}$ & $\begin{array}{c}\text { Second and Third } \\
\text { Lang. } \\
\text { relative to } \\
\text { Only Hebrew }\end{array}$ & $\begin{array}{c}\text { No Hebrew } \\
\text { Relative to } \\
\text { Only Hebrew }\end{array}$ \\
\hline INTERCEPT & $\begin{array}{l}0.9195 \\
(11.44)\end{array}$ & $\begin{array}{l}0.6451 \\
(5.84)\end{array}$ & $\begin{array}{l}1.5274 \\
(11.95)\end{array}$ \\
\hline AGE & $\begin{array}{l}0.0442 \\
(36.24)\end{array}$ & $\begin{array}{l}0.0890 \\
(48.41)\end{array}$ & $\begin{array}{c}0.1126 \\
(50.88)\end{array}$ \\
\hline EDUC & $\begin{array}{c}-0.0031 \\
(-1.30)\end{array}$ & $\begin{array}{l}-0.1025 \\
(-29.28)\end{array}$ & $\begin{array}{l}-0.1859 \\
(-43.18)\end{array}$ \\
\hline YSM & $\begin{array}{l}-0.0979 \\
(-22.23)\end{array}$ & $\begin{array}{l}-0.2406 \\
(-40.55)\end{array}$ & $\begin{array}{l}-0.3628 \\
(-56.59)\end{array}$ \\
\hline YSMSQ & $\begin{array}{l}0.0006 \\
(8.36)\end{array}$ & $\begin{array}{l}0.0018 \\
(13.87)\end{array}$ & $\begin{array}{l}0.0038 \\
(28.31)\end{array}$ \\
\hline MARR & $\begin{array}{c}-0.0814 \\
(-2.35)\end{array}$ & $\begin{array}{c}0.0012 \\
(0.02)\end{array}$ & $\begin{array}{c}-0.1883 \\
(-3.05)\end{array}$ \\
\hline MARROVER & $\begin{array}{c}0.1704 \\
(6.03)\end{array}$ & $\begin{array}{l}0.6542 \\
(16.69)\end{array}$ & $\begin{array}{l}0.5125 \\
(10.24)\end{array}$ \\
\hline CHILDREN & $\begin{array}{l}0.1033 \\
(0.39)\end{array}$ & $\begin{array}{c}-0.2151 \\
(-5.68)\end{array}$ & $\begin{array}{l}-0.4807 \\
(-10.92)\end{array}$ \\
\hline HCHILBIS & $\begin{array}{l}0.0081 \\
(0.28)\end{array}$ & $\begin{array}{c}-0.1810 \\
(-4.56)\end{array}$ & $\begin{array}{c}-0.4631 \\
(-9.96)\end{array}$ \\
\hline TEL-AVIV & $\begin{array}{c}-0.0065 \\
(-0.34)\end{array}$ & $\begin{array}{c}0.0169 \\
(0.56)\end{array}$ & $\begin{array}{c}0.0076 \\
(0.20)\end{array}$ \\
\hline JERUSALEM & $\begin{array}{l}0.0628 \\
(1.79)\end{array}$ & $\begin{array}{c}-0.0551 \\
(-0.99)\end{array}$ & $\begin{array}{c}-0.3454 \\
(-4.59)\end{array}$ \\
\hline ASIA & $\begin{array}{l}-0.3054 \\
(-12.36)\end{array}$ & $\begin{array}{l}-0.6780 \\
(-16.54)\end{array}$ & $\begin{array}{l}-1.0507 \\
(-19.40)\end{array}$ \\
\hline NORTHAFR & $\begin{array}{c}0.0403 \\
(1.49)\end{array}$ & $\begin{array}{c}-0.3462 \\
(-8.72)\end{array}$ & $\begin{array}{l}-0.7519 \\
(-15.24)\end{array}$ \\
\hline USSR & $\begin{array}{c}-0.2621 \\
(-6.35)\end{array}$ & $\begin{array}{c}-0.4518 \\
(-6.58)\end{array}$ & $\begin{array}{c}-0.1865 \\
(-2.56)\end{array}$ \\
\hline WESTEURO & $\begin{array}{c}0.2613 \\
(6.72)\end{array}$ & $\begin{array}{l}0.7274 \\
(11.29)\end{array}$ & $\begin{array}{l}0.5233 \\
(5.95)\end{array}$ \\
\hline ENGLSPEA & $\begin{array}{l}0.3041 \\
(2.60)\end{array}$ & $\begin{array}{l}1.6422 \\
(12.85)\end{array}$ & $\begin{array}{l}1.0617 \\
(7.04)\end{array}$ \\
\hline LATIAMER & $\begin{array}{l}0.5341 \\
(5.04)\end{array}$ & $\begin{array}{l}0.3305 \\
(2.53)\end{array}$ & $\begin{array}{l}0.2425 \\
(1.64)\end{array}$ \\
\hline $\begin{array}{l}\text { Chi Square } \\
\text { Sample Size }\end{array}$ & $\begin{array}{c}34,923.53 \\
81,602\end{array}$ & $\begin{array}{c}34,923.53 \\
81,602\end{array}$ & $\begin{array}{c}34,923.53 \\
81,602\end{array}$ \\
\hline
\end{tabular}

Dependent variable: HEBPRIML $=3$ if speaking Hebrew only, HEBPRIML $=2$ if Hebrew is primary language, HEBPRIML $=1$ if Hebrew is used as second or third language, and HEBPRIML $=0$ if individual does not speak Hebrew. Base category HEBPRIML=3.

$\mathrm{z}$ statistics are in parentheses.

Source: 1972 Census of Population and Housing, Israel, Public Use Sample, Demographic File, 20 percent sample of the population. 
Table 10.7

Predicted Probability of Being in each Language Category, Israel, 1972

(Foreign-Born Jewish Men, Age 25 to 64)

\begin{tabular}{|c|c|c|c|c|c|}
\hline Variable & Value & $\begin{array}{c}\text { Only } \\
\text { Hebrew }\end{array}$ & $\begin{array}{l}\text { Hebrew } \\
\text { Primary }\end{array}$ & $\begin{array}{c}\text { Hebrew } \\
\text { Second or } \\
\text { Third } \\
\end{array}$ & $\begin{array}{c}\text { No } \\
\text { Hebrew }\end{array}$ \\
\hline MEANS & & 0.2068 & 0.6477 & 0.1096 & 0.0359 \\
\hline BASE & & 0.1594 & 0.6538 & 0.1455 & 0.0412 \\
\hline \multirow[t]{3}{*}{ AGE } & 34 & 0.2502 & 0.6416 & 0.0887 & 0.0196 \\
\hline & 45 & 0.1567 & 0.6532 & 0.1478 & 0.0423 \\
\hline & 56 & 0.0891 & 0.6042 & 0.2238 & 0.0829 \\
\hline \multirow[t]{3}{*}{ EDUC } & 5 & 0.1409 & 0.5854 & 0.1957 & 0.0780 \\
\hline & 10 & 0.1629 & 0.6661 & 0.1354 & 0.0356 \\
\hline & 15 & 0.1782 & 0.7177 & 0.0888 & 0.0154 \\
\hline YSM & $16(256)$ & 0.1093 & 0.6243 & 0.2050 & 0.0613 \\
\hline \multirow[t]{2}{*}{ (\& YSMSQ) } & $27(728)$ & 0.2528 & 0.6528 & 0.0786 & 0.0158 \\
\hline & $38(1444)$ & 0.4083 & 0.5519 & 0.0327 & 0.0071 \\
\hline \multirow[t]{2}{*}{ MARR } & 1 & Base & Base & Base & Base \\
\hline & $\mathbf{0}$ & 0.1498 & 0.6667 & 0.1366 & 0.0468 \\
\hline \multirow[t]{2}{*}{ MARROVER } & 1 & 0.1242 & 0.6041 & 0.2181 & 0.0536 \\
\hline & $\mathbf{0}$ & Base & Base & Base & Base \\
\hline \multirow[t]{2}{*}{ CHILDREN } & 1 & Base & Base & Base & Base \\
\hline & $\mathbf{0}$ & 0.1600 & 0.5919 & 0.1811 & 0.0669 \\
\hline \multirow[t]{2}{*}{ HCHILBIS } & 1 & Base & Base & Base & Base \\
\hline & $\mathbf{0}$ & 0.1521 & 0.6189 & 0.1664 & 0.0625 \\
\hline TEL-AVIV & 1 & 0.1596 & 0.6505 & 0.1482 & 0.0416 \\
\hline JERUSALEM & 1 & 0.1559 & 0.6809 & 0.1347 & 0.0285 \\
\hline Rest of Israel & Base & Base & Base & Base & Base \\
\hline EASTEURO & 1 & 0.2104 & 0.6645 & 0.0928 & 0.0323 \\
\hline ASIA & 1 & 0.2774 & 0.6456 & 0.0621 & 0.0149 \\
\hline NORTHAFR & 1 & 0.2140 & 0.7038 & 0.0668 & 0.0155 \\
\hline USSR & 1 & 0.2605 & 0.6332 & 0.0732 & 0.0331 \\
\hline WESTEURO & 1 & Base & Base & Base & Base \\
\hline ENGLSPEA & 1 & 0.1249 & 0.5349 & 0.2848 & 0.0554 \\
\hline LATIAMER & 1 & 0.1389 & 0.7486 & 0.0853 & 0.0271 \\
\hline
\end{tabular}

Sample Size $=81,602$

Note: The base or reference person is a 44.6 year old Jewish male born in Western Europe with 9.1 years of schooling, who has lived in Israel 21.1 years, and is married but married after coming to Israel, has children born in Israel and does not live in Tel Aviv or Jerusalem. Row totals may not add to 1.0000 due to rounding. Multinomial logit coefficients obtained from table 6.

Source: 1972 Census of Population and Housing, Israel, Public Use Sample, Demographic File, 20 percent sample of the population. 
Table 10.8

Mean Earnings by HebreW language SKILlS

(Foreign-Born Jewish Men, Age 25 to 64, with Positive Gross Annual Earnings, Wage and Salaried Workers, Israel, 1972)

\begin{tabular}{c|ccccc}
\hline \multirow{3}{*}{$\begin{array}{c}\text { WrITING } \\
\text { HEBREW }\end{array}$} & Only & Primary & $\begin{array}{c}\text { Second or } \\
\text { Third }\end{array}$ & No Hebrew & Total \\
\cline { 2 - 6 } Yes & $12,310.88$ & $12,518.10$ & $11,034.99$ & $9,996.84$ & $12,229.08$ \\
& $(14,708)$ & $(32,160)$ & $(5,352)$ & $(1,840)$ & $(54,060)$ \\
& {$[7,315.59]$} & {$[7,736.96)$} & {$[8,276.64]$} & {$[7,217.98]$} & {$[7,686.70]$} \\
& $7,594.10$ & $8,024.56$ & $7,782.43$ & $6,952.52$ & $7,563.29$ \\
No & $(705)$ & $(2,865)$ & $(3,029)$ & $(3,286)$ & $(9,885)$ \\
& {$[4,983.46]$} & {$[4,956.33]$} & {$[4,894.87]$} & {$[5,975.12]$} & {$[5,319.15]$} \\
& $12,095.13$ & $12,150.54$ & $9,859.47$ & $8,045.29$ & $11,507.81$ \\
& $(15,413)$ & $(35,025)$ & $(8,381)$ & $(5,126)$ & $(63,945)$ \\
& {$[7,292.14]$} & {$[7,647.83]$} & {$[7,405.50]$} & {$[6,611.50]$} & {$[7,561.08]$} \\
\hline \multirow{3}{*}{ Total } & & & & & \\
\hline
\end{tabular}

Number of cases $(\mathrm{N})$ are in parentheses.

Standard deviations (STD) are in brackets.

Earnings in 1972 Israeli Lira.

Source: 1972 Census of Population and Housing, Israel, Public Use Sample, Demographic File, 20 percent sample of the population. 
Table 10.9

ANALYSIS OF EARNINGS WITH LANGUAGE VARIABLES, ISRAEL, 1972

(Foreign-Born Jewish Men, Age 25 to 64, with Positive Gross Annual Earnings, Wage and Salaried Workers)

\begin{tabular}{|c|c|c|c|c|}
\hline VARIABLES & (1) & (2) & (3) & (4) \\
\hline CONSTANT & $\begin{array}{c}7.8380 \\
(416.80)\end{array}$ & $\begin{array}{c}7.7994 \\
(412.21)\end{array}$ & $\begin{array}{c}7.9506 \\
(401.86)\end{array}$ & $\begin{array}{c}7.9545 \\
(400.71)\end{array}$ \\
\hline EDUC & $\begin{array}{l}0.0441 \\
(63.97)\end{array}$ & $\begin{array}{l}0.0433 \\
(62.70)\end{array}$ & $\begin{array}{l}0.0429 \\
(62.07)\end{array}$ & $\begin{array}{l}0.0413 \\
(59.01)\end{array}$ \\
\hline EXP & $\begin{array}{l}0.0304 \\
(36.14)\end{array}$ & $\begin{array}{l}0.0305 \\
(36.25)\end{array}$ & $\begin{array}{l}0.0300 \\
(35.51)\end{array}$ & $\begin{array}{l}0.0305 \\
(36.04)\end{array}$ \\
\hline EXPSQ & $\begin{array}{l}-0.0006 \\
(-40.43)\end{array}$ & $\begin{array}{l}-0.0005 \\
(-38.81)\end{array}$ & $\begin{array}{l}-0.0005 \\
(-38.00)\end{array}$ & $\begin{array}{l}-0.0005 \\
(-38.25)\end{array}$ \\
\hline MARR & $\begin{array}{l}0.3044 \\
(35.25)\end{array}$ & $\begin{array}{l}0.3038 \\
(35.14)\end{array}$ & $\begin{array}{l}0.3029 \\
(35.06)\end{array}$ & $\begin{array}{l}0.3032 \\
(35.15)\end{array}$ \\
\hline YSM & $\begin{array}{l}0.0273 \\
(33.76)\end{array}$ & $\begin{array}{l}0.0224 \\
(26.27)\end{array}$ & $\begin{array}{l}0.0212 \\
(24.66)\end{array}$ & $\begin{array}{l}0.0216 \\
(25.17)\end{array}$ \\
\hline YSMSQ & $\begin{array}{l}-0.0003 \\
(-17.60)\end{array}$ & $\begin{array}{l}-0.0002 \\
(-14.18)\end{array}$ & $\begin{array}{l}-0.0002 \\
(-13.06)\end{array}$ & $\begin{array}{l}-0.0002 \\
(-14.01)\end{array}$ \\
\hline TEL-AVIV & $\begin{array}{c}-0.0163 \\
(-3.19)\end{array}$ & $\begin{array}{c}-0.0159 \\
(-3.10)\end{array}$ & $\begin{array}{c}-0.0159 \\
(-3.10)\end{array}$ & $\begin{array}{c}-0.0168 \\
(-3.28)\end{array}$ \\
\hline JERUSALEM & $\begin{array}{c}-0.0457 \\
(-4.99)\end{array}$ & $\begin{array}{c}-0.0484 \\
(-5.28)\end{array}$ & $\begin{array}{c}-0.0498 \\
(-5.45)\end{array}$ & $\begin{array}{c}-0.0524 \\
(-5.73)\end{array}$ \\
\hline ASIA & $\begin{array}{l}-0.2037 \\
(-30.45)\end{array}$ & $\begin{array}{l}-0.2117 \\
(-31.60)\end{array}$ & $\begin{array}{l}-0.2136 \\
(-31.86)\end{array}$ & $\begin{array}{l}-0.2069 \\
(-27.47)\end{array}$ \\
\hline NORTHAFR & $\begin{array}{l}-0.1376 \\
(-20.87)\end{array}$ & $\begin{array}{l}-0.1482 \\
(-22.42)\end{array}$ & $\begin{array}{l}-0.1523 \\
(-23.04)\end{array}$ & $\begin{array}{l}-0.1419 \\
(-19.24)\end{array}$ \\
\hline USSR & $\begin{array}{l}-0.1142 \\
(-10.45)\end{array}$ & $\begin{array}{l}-0.1166 \\
(-10.69)\end{array}$ & $\begin{array}{l}-0.1121 \\
(-10.28)\end{array}$ & $\begin{array}{l}-0.1117 \\
(-10.25)\end{array}$ \\
\hline WESTEURO & $\begin{array}{l}0.0073 \\
(0.68)\end{array}$ & $\begin{array}{l}0.0150 \\
(1.39)\end{array}$ & $\begin{array}{l}0.0141 \\
(1.30)\end{array}$ & $\begin{array}{l}0.0016 \\
(0.15)\end{array}$ \\
\hline ENGLSPEA & $\begin{array}{c}0.1989 \\
(9.02)\end{array}$ & $\begin{array}{l}0.2229 \\
(10.11)\end{array}$ & $\begin{array}{l}0.2078 \\
(9.42)\end{array}$ & $\begin{array}{l}0.0867 \\
(3.65)\end{array}$ \\
\hline LATIAMER & $\begin{array}{c}0.0799 \\
(3.57)\end{array}$ & $\begin{array}{l}0.0722 \\
(3.23)\end{array}$ & $\begin{array}{l}0.0680 \\
(3.04)\end{array}$ & $\begin{array}{c}0.0708 \\
(3.18)\end{array}$ \\
\hline HEBSOP & - & $\begin{array}{l}0.1282 \\
(18.79)\end{array}$ & - & - \\
\hline HEBPRIM & - & - & $\begin{array}{l}0.0047 \\
(0.81)\end{array}$ & $\begin{array}{c}-0.0015 \\
(-0.24)\end{array}$ \\
\hline НЕВSECTH & - & - & $\begin{array}{c}-0.0854 \\
(-9.53)\end{array}$ & $\begin{array}{l}-0.0941 \\
(-10.05)\end{array}$ \\
\hline HEBNONE & - & - & $\begin{array}{l}-0.2082 \\
(-18.80)\end{array}$ & $\begin{array}{l}-0.2217 \\
(-19.36)\end{array}$ \\
\hline ENGLOPS & - & - & - & $\begin{array}{l}0.1597 \\
(14.02)\end{array}$ \\
\hline ARABOPS & - & - & - & $\begin{array}{c}-0.0240 \\
(-3.21)\end{array}$ \\
\hline $\begin{array}{l}R^{2} \text { adj. } \\
\text { Sample Size }\end{array}$ & $\begin{array}{l}0.2427 \\
61,622\end{array}$ & $\begin{array}{l}0.2466 \\
61,416\end{array}$ & $\begin{array}{l}0.2483 \\
61,416\end{array}$ & $\begin{array}{l}0.2510 \\
61,416\end{array}$ \\
\hline
\end{tabular}

Dependent Variable: Natural Logarithm of Gross Annual Earnings for Wage and Salaried Workers. $\mathrm{t}$ ratios are in parentheses. Earnings in 1972 Israeli Lira.

Source: 1972 Census of Population and Housing, Israel, Public Use Sample, Demographic File, 20 percent sample of the population. 
Table 10.10

ANALYSIS OF EARNINGS WITH LANGUAGE AND WRITING VARIABLES, Israel, 1972

(Foreign-Born Jewish Men, Age 25 to 64, with Positive Gross Annual Earnings, Wage and Salaried Workers)

\begin{tabular}{|c|c|c|c|c|}
\hline VARIABLES & (1) & (2) & (3) & (4) \\
\hline CONSTANT & $\begin{array}{c}7.8042 \\
(411.01)\end{array}$ & $\begin{array}{c}7.7814 \\
(407.96)\end{array}$ & $\begin{array}{c}7.7780 \\
(402.11)\end{array}$ & $\begin{array}{c}7.9769 \\
(400.43)\end{array}$ \\
\hline EDUC & $\begin{array}{l}0.0405 \\
(56.12)\end{array}$ & $\begin{array}{l}0.0408 \\
(56.39)\end{array}$ & $\begin{array}{l}0.0408 \\
(56.37)\end{array}$ & $\begin{array}{l}0.0408 \\
(56.37)\end{array}$ \\
\hline $\mathbf{T}$ & $\begin{array}{l}0.0299 \\
(35.37)\end{array}$ & $\begin{array}{l}0.0301 \\
(35.60)\end{array}$ & $\begin{array}{l}0.0301 \\
(35.53)\end{array}$ & $\begin{array}{l}0.0301 \\
(35.53)\end{array}$ \\
\hline TSQ & $\begin{array}{l}-0.0005 \\
(-38.35)\end{array}$ & $\begin{array}{l}-0.0005 \\
(-37.46)\end{array}$ & $\begin{array}{l}-0.0005 \\
(-37.42)\end{array}$ & $\begin{array}{l}-0.0005 \\
(-37.42)\end{array}$ \\
\hline MARR & $\begin{array}{l}0.3033 \\
(35.02)\end{array}$ & $\begin{array}{l}0.3030 \\
(34.90)\end{array}$ & $\begin{array}{l}0.3030 \\
(34.90)\end{array}$ & $\begin{array}{l}0.3030 \\
(34.90)\end{array}$ \\
\hline YSM & $\begin{array}{l}0.0247 \\
(29.73)\end{array}$ & $\begin{array}{l}0.0213 \\
(24.67)\end{array}$ & $\begin{array}{l}0.0213 \\
(24.67)\end{array}$ & $\begin{array}{l}0.0213 \\
(24.67)\end{array}$ \\
\hline YSMSQ & $\begin{array}{l}-0.0003 \\
(-15.82)\end{array}$ & $\begin{array}{l}-0.0002 \\
(-13.45)\end{array}$ & $\begin{array}{l}-0.0002 \\
(-13.43)\end{array}$ & $\begin{array}{l}-0.0002 \\
(-13.43)\end{array}$ \\
\hline TEL-AVIV & $\begin{array}{c}-0.0176 \\
(-3.43)\end{array}$ & $\begin{array}{c}-0.0171 \\
(-3.32)\end{array}$ & $\begin{array}{c}-0.0171 \\
(-3.33)\end{array}$ & $\begin{array}{c}-0.0171 \\
(-3.33)\end{array}$ \\
\hline JERUSALEM & $\begin{array}{c}-0.0477 \\
(-5.20)\end{array}$ & $\begin{array}{c}-0.0499 \\
(-5.42)\end{array}$ & $\begin{array}{c}-0.0500 \\
(-5.43)\end{array}$ & $\begin{array}{c}-0.0500 \\
(-5.43)\end{array}$ \\
\hline ASIA & $\begin{array}{l}-0.2041 \\
(-30.37)\end{array}$ & $\begin{array}{l}-0.2096 \\
(-31.13)\end{array}$ & $\begin{array}{l}-0.2097 \\
(-31.14)\end{array}$ & $\begin{array}{l}-0.2097 \\
(-31.14)\end{array}$ \\
\hline NORTHAFR & $\begin{array}{l}-0.1408 \\
(-21.23)\end{array}$ & $\begin{array}{l}-0.1484 \\
(-22.31)\end{array}$ & $\begin{array}{l}-0.1485 \\
(-22.32)\end{array}$ & $\begin{array}{l}-0.1485 \\
(-22.32)\end{array}$ \\
\hline USSR & $\begin{array}{l}-0.1120 \\
(-10.25)\end{array}$ & $\begin{array}{l}-0.1143 \\
(-10.47)\end{array}$ & $\begin{array}{l}-0.1141 \\
(-10.45)\end{array}$ & $\begin{array}{l}-0.1141 \\
(-10.45)\end{array}$ \\
\hline WESTEURO & $\begin{array}{l}0.0140 \\
(1.29)\end{array}$ & $\begin{array}{l}0.0188 \\
(1.734)\end{array}$ & $\begin{array}{l}0.0187 \\
(1.72)\end{array}$ & $\begin{array}{c}0.01867 \\
(1.72)\end{array}$ \\
\hline ENGLSPEA & $\begin{array}{l}0.2014 \\
(9.15)\end{array}$ & $\begin{array}{l}0.2214 \\
(10.05)\end{array}$ & $\begin{array}{l}0.2200 \\
(9.96)\end{array}$ & $\begin{array}{l}0.2200 \\
(9.96)\end{array}$ \\
\hline LATIAMER & $\begin{array}{l}0.0808 \\
(3.62)\end{array}$ & $\begin{array}{l}0.0752 \\
(3.36)\end{array}$ & $\begin{array}{l}0.0748 \\
(3.35)\end{array}$ & $\begin{array}{c}0.0748 \\
(3.0 .35)\end{array}$ \\
\hline HEBWRIT & $\begin{array}{l}0.1216 \\
(15.60)\end{array}$ & $\begin{array}{l}0.0888 \\
(10.97)\end{array}$ & $\begin{array}{l}0.0959 \\
(9.08)\end{array}$ & - \\
\hline HEBSOP & - & $\begin{array}{l}0.1072 \\
(15.00)\end{array}$ & $\begin{array}{l}0.1183 \\
(9.23)\end{array}$ & - \\
\hline HEBSPWR & - & - & $\begin{array}{c}-0.0153 \\
(-1.05)\end{array}$ & - \\
\hline YSPNWR & - & - & - & $\begin{array}{c}-0.0806 \\
(-7.16)\end{array}$ \\
\hline NSPYWR & - & - & - & $\begin{array}{l}-0.1030 \\
(-12.60)\end{array}$ \\
\hline NSPNWR & - & - & - & $\begin{array}{l}-0.1989 \\
(-20.52)\end{array}$ \\
\hline $\begin{array}{l}R^{2} \text { adj. } \\
\text { Sample Size }\end{array}$ & $\begin{array}{l}0.2430 \\
60,893\end{array}$ & $\begin{array}{l}0.2453 \\
60,689\end{array}$ & $\begin{array}{l}0.2453 \\
60,689\end{array}$ & $\begin{array}{l}0.2453 \\
60,689\end{array}$ \\
\hline
\end{tabular}

Dependent Variable: Natural Logarithm of Gross Annual Earnings for Wage and Salaried Workers. $\mathrm{t}$ ratios are in parentheses. Earnings in 1972 Israeli Lira.

Source: 1972 Census of Population and Housing, Israel, Public Use Sample, Demographic File, 20 percent sample of the population. 


\section{Endnotes}

${ }^{1}$ Few survey data sets on immigrants include information on literacy, that is, reading and/or writing skills. Studies that have examined immigrant literacy in the destination language include Beenstock (1993) for Israel, Rivera-Batiz (1996), Chiswick (1991), Chiswick and Miller (1998b and 1999) for the United States, Kee (1993) for the Netherlands and Dustmann (1993) for Germany. Compared to the census, these studies tend to analyze relatively small samples of selected foreign-born populations.

${ }^{2}$ The Israeli Census is similar to censuses in other major immigrant receiving countries in not asking about specific pre-immigration experiences, other than country of birth.

${ }^{3}$ For an interesting newspaper article on children serving as translators for their immigrant parents in the United States, see Hedges, 2000.

${ }^{4}$ Unlike the case of English among immigrants in the English-speaking developed countries, immigrants to Israel with a higher level of schooling are not more likely than their less educated counterparts to have been exposed to Hebrew in their pre-immigration secular schooling.

${ }^{5}$ The automatic granting of Israeli citizenship to Jewish immigrants at entry means that this is not a relevant variable for Israel. 
${ }^{6}$ These regions are Jerusalem, Northern, Haifa, Central, Tel Aviv, Southern, and two very small groups, Jewish localities in the occupied territories (West Bank and Gaza) and area not specified.

${ }^{7}$ These languages in order of frequency are Arabic, Yiddish, German, Romanian, French, Spanish-Ladino, Polish, English, Hungarian, Persian, Russian, and Kurdish. The substantive findings are unchanged if CONPR is expanded to include second or tertiary languages spoken.

${ }^{8}$ For example, although in the 1972 Census among immigrants in Israel 6 to 10 years 8 percent spoke only Hebrew and 52 percent spoke Hebrew as an only or primary language, eleven years later in the 1983 Census, the cohort in Israel 16 to 20 years reported 19 percent and 79 percent, respectively. This is very similar to the 21 percent and 77 percent, speaking only Hebrew or Hebrew as the only or primary language, respectively, among immigrants in the country 16 to 20 years as reported in the 1972 Census. See Table 2 and Chiswick (1998).

${ }^{9}$ As the mean of the dependent variable is 0.75 , multiplying the logit coefficients by 0.188 gives a partial effect that can be compared to the OLS coefficients. The majority of the effects in the logit model are slightly stronger than in the OLS model. 
${ }^{10}$ The cross-tabulation of writing and speaking among adult foreign-born men expressed in percents, is:

\section{Speaking Hebrew}

Writing Only Primary Second or Third $\quad$ No Hebrew Total

$\begin{array}{lrrrrr}\text { Yes } & 23.2 & 47.9 & 8.5 & 3.1 & 82.7 \\ \text { No } & 1.3 & 4.8 & 5.2 & 6.1 & 17.3 \\ \text { Total } & 24.5 & 52.7 & 13.7 & 9.2 & 100.0\end{array}$

${ }^{11}$ Because the construction of the language concentration variable (CONPR) involves assigning values of zero to all individuals in the "Only Hebrew" category, the language concentration variable cannot be included in the multinomial logit model.

${ }^{12}$ Other studies of the labor market adjustment of immigrants in Israel using various census and survey data include Beenstock (1993, 1996b), Beenstock and Ben-Menachem (1997), Chiswick (1998), Eckstein and Shachar (1995), Eckstein and Weiss (1998), Friedberg (2000), Neuman (1998), and Raijman and Semyonov (1998).

${ }^{13}$ The dichotomous variables ENGLOPS and ARABOPS are unity for those who speak English and Arabic, respectively, on a daily basis as their only, primary or secondary language.

${ }^{14}$ The effect of country of origin on earnings among immigrants in Israel from the high wage, high return migration English-speaking developed countries is presumably reflected in the coefficient of the English-speaking country of origin variable. 
${ }^{15}$ If going from lacking proficiency to having proficiency increases annual earnings by $100 \mathrm{~b}$ percent, and if $\mathrm{k}$ is the cost of the investment expressed in full-year potential earnings, the rate of return on the investment is approximately $r=b / k$. In this example, $b=$ $0.20, \mathrm{k}=1.0$ and the rate of return on the investment is approximately 20 percent. If the cost were nine months potential earnings, the rate of return would be approximately $r=$ $0.20 / .75=26.6$, or approximately 27 percent. 


\section{IZA Discussion Papers}

No. Author(s)

81

T. J. Hatton

S. Wheatley Price

82

K. A. Konrad

83

R. Euwals

84

C. M. Schmidt

85

S. Pudney

M. A. Shields

86

J.P. Haisken-DeNew

C. M. Schmidt

87

T. K. Bauer

88

O. Bover

P. Velilla

89

S. Neuman

90

H. Lehmann

J. Wadsworth

91

M. Lechner

92

R. E. Wright

93

M. Lechner

94

M. Eichler

M. Lechner

95
P. Cahuc
A. Zylberberg

96

P. Cahuc

A. Zylberberg
Title

Area

Date

Migration, Migrants and Policy in the United

1

$12 / 99$

Kingdom

Privacy, time consistent optimal labor income

3

$12 / 99$

taxation and education policy

Female Labour Supply, Flexibility of Working Hours, 1 and Job Mobility in the Netherlands

The Heterogeneity and Cyclical Sensitivity of 1 Unemployment: An Exploration of German Labor Market Flows

Gender and Racial Discrimination in Pay and 5/6 Promotion for NHS Nurses

Money for Nothing and Your Chips for Free?

The Anatomy of the PC Wage Differential

Educational Mismatch and Wages in Germany

1

Migration in Spain: Historical Background and 1

Current Trends

Aliyah to Israel: Immigration under Conditions of 1 Adversity

Tenures that Shook the World: Worker Turnover in 4

Russia, Poland and Britain

Identification and Estimation of Causal Effects of 6

Multiple Treatments Under the Conditional

Independence Assumption

The Rate of Return to Private Schooling

5

$12 / 99$

An Evaluation of Public-Sector-Sponsored

6

Continuous Vocational Training Programs in East

Germany

An Evaluation of Public Employment Programmes 6

in the East German State of Sachsen-Anhalt

$12 / 99$

Job Protection, Minimum Wage and Unemployment 3

$12 / 99$

Redundancy Payments, Incomplete Labor

3

$12 / 99$

Contracts, Unemployment and Welfare 
N. Smith

102 B. van der Klaauw J. C. van Ours

\section{K. Brännäs}

G. Brunello

C. Graziano

B. Parigi

106 L. Bellmann

S. Bender

U. Hornsteiner

109 G. J. van den Berg B. van der Klaauw T. Schank
Labor Supply and Matching Rates for Welfare

Characteristics

Estimation in a Duration Model for Evaluating

Different Skill Levels and Firing Costs in a

Matching Model with Uncertainty -

An Extension of Mortensen and Pissarides (1994)

Ownership or Performance: What Determines

Board of Directors' Turnover in Italy?

Job Tenure of Two Cohorts of Young German Men 1979 - 1990: An analysis of the (West-)German Employment Statistic Register Sample concerning multivariate failure times and unobserved heterogeneity

Fast Track or Failure: A Study of the Completion Rates of Graduate Students in Economics

Modeling Financial Incentives to Get Unemployed $3 / 6$

Back to Work

Combining Micro and Macro Unemployment

A Theory of Social Forces and Immigrant Second

A Comparative Look at the Czech Republic

Heterogeneous Labour: New Evidence from a Matched Employer-Employee Data-Set

Do Mandatory Pensions Decrease Household 
114 G. Brunello

A. Medio

115 A. Cigno

F. C. Rosati

116 C. Belzil

117 S. Bender
A. Haas
C. Klose

118 M. A. Shields M. E. Ward

119 A. Lindbeck

D. J. Snower

120 P. T. Pereira

P. S. Martins

121 J. C. van Ours

122 D. Munich

J. Svejnar

K. Terrell

123 J. Hunt

124 R. T. Riphahn

125 F. Büchel

J. R. Frick

126 J. Fersterer

R. Winter-Ebmer

127

M. Karanassou

D. J. Snower

128 O. Ashenfelter

D. Ashmore

O. Deschênes

129 B. R. Chiswick M. E. Hurst

130 G. Brunello

S. Comi

C. Lucifora

131 B. R. Chiswick
An Explanation of International Differences in

2 $2 / 00$

Education and Workplace Training

Why do Indian Children Work, and is it Bad for

3 Them?

Unemployment Insurance and Subsequent Job

3

Duration: Job Matching vs. Unobserved

Heterogeneity

IAB Employment Subsample 1975-1995.

Opportunities for Analysis Provided by the

Anonymised Subsample

Improving Nurse Retention in the British National

Health Service: The Impact of Job Satisfaction on

Intentions to Quit

The Division of Labor and the Market for

Organizations

5

$2 / 00$

Does Education Reduce Wage Inequality?

Quantile Regressions Evidence from Fifteen

European Countries

5

$2 / 00$

Do Active Labor Market Policies Help Unemployed $\quad$ 4/6

Workers to Find and Keep Regular Jobs?

Returns to Human Capital under the Communist

Wage Grid and During the Transition to a Market

Economy

Why Do People Still Live in East Germany?

Rational Poverty or Poor Rationality? The Take-up of Social Assistance Benefits

The Income Portfolio of Immigrants in Germany -

Effects of Ethnic Origin and Assimilation. Or:

Who Gains from Income Re-Distribution?

Smoking, Discount Rates, and Returns to

Education

Characteristics of Unemployment Dynamics: The

Chain Reaction Approach

Do Unemployment Insurance Recipients Actively

Seek Work? Evidence From Randomized Trials in

Four U.S. States

The Employment, Unemployment and

Unemployment Compensation Benefits of

Immigrants

The Returns to Education in Italy: A New Look at the Evidence

Are Immigrants Favorably Self-Selected? An

Economic Analysis
$3 / 00$

$3 / 00$

5

$3 / 00$

$3 / 00$

$3 / 00$

$3 / 00$

$3 / 00$

$3 / 00$

$3 / 00$

$1 / 3 \quad 3 / 00$

1

$3 / 00$ 
Hours and Wages in the Depression: British Engineering, 1926-1938

133 D. N. F. Bell

R. A. Hart

O. Hübler

W. Schwerdt

134 A. D. Kugler

G. Saint-Paul

135 A. Barrett

P. J. O'Connell

136 M. Bräuninger

M. Pannenberg

137 J.-St. Pischke

138 J. Zweimüller

R. Winter-Ebmer

139 R. A. Hart

Y. Ma

140 G. Brunello

S. Comi

141 R. Hujer

M. Wellner

142 J. J. Dolado

F. Felgueroso

J. F. Jimeno

143 P. J. Luke

M. E. Schaffer

144 G. Saint-Paul

145 M.-S. Yun

146 T. K. Bauer

J. P. Haisken-DeNew

147 M. Belot

J. C. van Ours

148 L. Goerke

149 R. Lalive

J. C. van Ours

J. Zweimüller
Paid and Unpaid Overtime Working in Germany and 1 the UK

$3 / 00$

Hiring and Firing Costs, Adverse Selection and

3

$3 / 00$

Long-term Unemployment

Is There a Wage Premium for Returning Irish

1

$3 / 00$

Migrants?

Unemployment and Productivity Growth: An

3

$3 / 00$

Empirical Analysis within the Augmented Solow

Model

Continuous Training in Germany

$3 / 00$

Firm-specific Training: Consequences for Job

$3 / 00$

Mobility

Wages, Hours and Human Capital over the

Life Cycle

Education and Earnings Growth: Evidence from $11 \quad 2 / 5 \quad 4 / 00$

European Countries

The Effects of Public Sector Sponsored Training on

Individual Employment Performance in East

Germany

Explaining Youth Labor Market Problems in Spain: 3

Crowding-Out, Institutions, or Technology Shifts?

$4 / 00$

Wage Determination in Russia: An Econometric 4

Investigation

Flexibility vs. Rigidity: Does Spain have the worst of 1 both Worlds?

Decomposition Analysis for a Binary Choice Model

Employer Learning and the Returns to Schooling

Does the Recent Success of Some OECD

Countries in Lowering their Unemployment Rates

Lie in the Clever Design of their Labour Market

Reforms?

Employment Effects of Labour Taxation in an Efficiency Wage Model with Alternative Budget Constraints and Time Horizons

The Impact of Active Labor Market Programs and Benefit Entitlement Rules on the Duration of Unemployment
7

$4 / 00$

5

$4 / 00$

$4 / 00$

$4 / 00$

$3 \quad 4 / 00$

3

$5 / 00$

$3 / 6 \quad 5 / 00$ 
A Comparison of the Human Capital and Signaling Models: The Case of the Self-Employed and the Increase in the Schooling Premium in the 1980's

Public Employment and Redistributive Politics: $\quad 4$ 

between Skilled and Unskilled Blue-Collar Workers within Establishments: An Empirical Analysis with Data of Manufacturing Firms 